\title{
Epidemiological Features of Human Cases After Bites/ Scratches From Rabies-suspected Animals in Zenica-Doboj Canton, Bosnia and Herzegovina
}

\author{
Selma Uzunović , Muhamed Skomorac ${ }^{2}$, Fatima Bašić ${ }^{2}$, Ivona Mijač-Musić \\ ${ }^{1}$ Department for Clinical Microbiology, Institute for Health and Food Safety Zenica, Zenica, Bosnia and Herzegovina; ${ }^{2}$ Department for \\ Epidemiology, Institute for Health and Food Safety Zenica, Zenica, Bosnia and Herzegovina
}

Objectives: To determine the epidemiological features of patients and animals after bites/scratches from rabies-suspected animals in Zenica-Doboj Canton, Bosnia and Herzegovina.

Methods: Data from all patients (and the causative animals) admitted to the Antirabies Service of the Institute for Health and Food Safety Zenica in the 2009-2017 period were analyzed, including age, sex, anatomical site of the bite/scratch, animal type (stray/ owned/wildlife), veterinary observations of the animal, and whether antirabies post-exposure prophylaxis (PEP) was indicated and/or administered.

Results: In total, 1716 patients were admitted. Bites/scratches were most frequently recorded during April and May $(n=181,10.5 \%$ and $n=163,9.5 \%$, respectively). The persons admitted were mostly from the Zenica municipality ( $n=1278,74.5 \%$; incidence: 11.55 / 1000 ), which is $66.6 \%$ urbanized. Males were more frequently represented $(n=1089,63.6 \%)$. The patients were mostly 50-64 and 2549 years of age ( $n=425,24.7 \%$ and $n=390,22.7 \%$, respectively). Dog bites were the most common cause $(n=1634,95.1 \%$, of which $n=1258,77.0 \%$ were caused by stray dogs). PEP was indicated for $997(58.1 \%)$ patients. Only $340(19.9 \%)$ animals underwent veterinary observations (3.1\% of stray and $76.1 \%$ of owned animals). The largest number of injuries were presented at lower extremities, $1044(60.8 \%)$ cases.

Conclusions: Zenica-Doboj Canton is a rabies-free region. Due to the high rate of stray animals not undergoing veterinary observations, the non-existence of a unique dog registry, and the consequent lack of information about stray animals in terms of number, vaccination, neutering, and euthanasia, there is an urgent need for improving the prevention and control of rabies within the One Health framework.

Key words: Animals, Humans, One Health, Post-exposure prophylaxis, Bosnia and Herzegovina

Received: October 31, 2018 Accepted: April 2, 2019

Corresponding author: Selma Uzunović, MD, PhD Department for Clinical Microbiology, Institute for Health and Food Safety Zenica, 2 Fra Ivana Jukića, Zenica 72000, Bosnia and Herzegovina

E-mail: selma_kamb@yahoo.com

This is an Open Access article distributed under the terms of the Creative Commons Attribution Non-Commercial License (http://creativecommons.org/licenses/bync/4.0/) which permits unrestricted non-commercial use, distribution, and reproduction in any medium, provided the original work is properly cited.

\section{INTRODUCTION}

Rabies is an emerging, and in some countries endemic, zoonotic disease representing a serious threat to the health of humans and animals, and to global health safety. Rabies is an infectious viral disease that is almost always fatal when clinical signs appear [1-3]. It is estimated that the virus endangers 59000 human lives annually, mostly among populations without adequate health services, especially in Africa and Asia [4]. 
Over $95 \%$ of rabies deaths in humans result from virus transmission through the bites of infected dogs [5]. Rabies is a $100 \%$ preventable disease through timely administration of post-exposure prophylaxis (PEP) to bite victims; however, fatalities still occur in many endemic countries [6].

The European Rabies Surveillance System was established in 1977. At that time, wildlife rabies accounted for $87.6 \%$ of cases, of which $74.2 \%$ occurred in foxes. Among domestic animals, cat rabies was most common, with $4.7 \%$, followed by cattle and dogs, which accounted for $3.3 \%$ and $2.5 \%$ of the cases, respectively [7].

Dog-mediated and wildlife rabies was prevalent in Bosnia and Herzegovina (B\&H) for many years [8]. From 1946 (after World War II) to 1957, B\&H accounted for more than half of the wolf rabies cases and more than a third of rabid foxes in the entire Socialist Federal Republic of Yugoslavia, which at that time contained $\mathrm{B} \& \mathrm{H}$. The estimated dog population in $\mathrm{B} \& \mathrm{H}$ was 200000 , of which $40-50 \%$ were vaccinated and about 10\% destroyed annually [8]. In 1971, a dog rabies outbreak emerged in northeastern $\mathrm{B} \& \mathrm{H}$, where rabies had been absent since 1964, probably because of a significant increase in the number of stray dogs in that region; the epizootic was eliminated by reinforced dog vaccination and other control activities [9].

Rabies in the Socialist Federal Republic of Yugoslavia, including B\&H as 1 of its 6 constituent republics, was reported in 1977 in the first issue of the Rabies Bulletin Europe [10]. Sylvatic rabies spread from the north to B\&H in 1982, and it was diagnosed in 13 foxes, 2 cattle, and 1 wild cat. In 1983, the epizootic further spread to the central and eastern regions, and 92 rabies cases, of which 68 were foxes, were reported [11].

After signing of the Dayton Peace Agreement, autonomous B\&H was divided into 3 administrative units, known as entities: the Federation of Bosnia and Herzegovina (FB\&H), Republic of Srpska (RS), and Brčko District (BD). The first rabies cases from autonomous B\&H were reported in the World Health Organization (WHO) Rabies Bulletin Europe 2001, in 15 foxes and 1 pine marten (wild animals), and 1 dog, bovine, and sheep. The rabid animals were mostly ( 2 domestic and 5 wild animal rabies cases) from Zenica-Doboj Canton, in central Bosnia. No human cases were recorded [12].

Several studies have investigated rabies infections in $\mathrm{B} \& \mathrm{H}$, but all have been conducted in the distant history of B\&H, which was part of the Kingdom of Serbs, Croats, and Slovenes until World War II and the Socialist Federal Republic of Yugoslavia until $1991[8,9,11]$. In the recent history of B\&H (after 1991), a single study has been published on the molecular epidemiology of rabies viruses isolated from foxes, dogs and a cat [13]. To our knowledge, no studies have been conducted to evaluate the epidemiological features of human cases after bites/ scratches from rabies-suspected animals, including age, sex, seasonality, type of animal, anatomical site of bite/scratches, and PEP administration.

The aim of this study was to determine the epidemiological features of human cases after bites/scratches from rabies-suspected animals in Zenica-Doboj Canton in B\&H.

\section{METHODS}

\section{Study Setting}

Zenica-Doboj Canton is situated in the central part of B\&H, which is located in the Balkan Peninsula in southeastern Europe (Figure 1). The cantonal capital is Zenica (30.4\% of the canton population). Its area is $3904 \mathrm{~km}^{2}(7.6 \%$ of the B\&H area of $51129 \mathrm{~km}^{2}$ ). Zenica-Doboj Canton includes 12 municipalities, which together have a population of 364433 (approximately $10 \%$ of the B\&H population) in 2 distinct residential zones: an urban zone with 126940 (34.8\%) inhabitants, and an agricultural rural zone with 237493 (65.2\%) inhabitants.

\section{Study Design and Participants}

A retrospective analysis of all human cases admitted to the Rabies Service of the Epidemiology Department of the Insti-

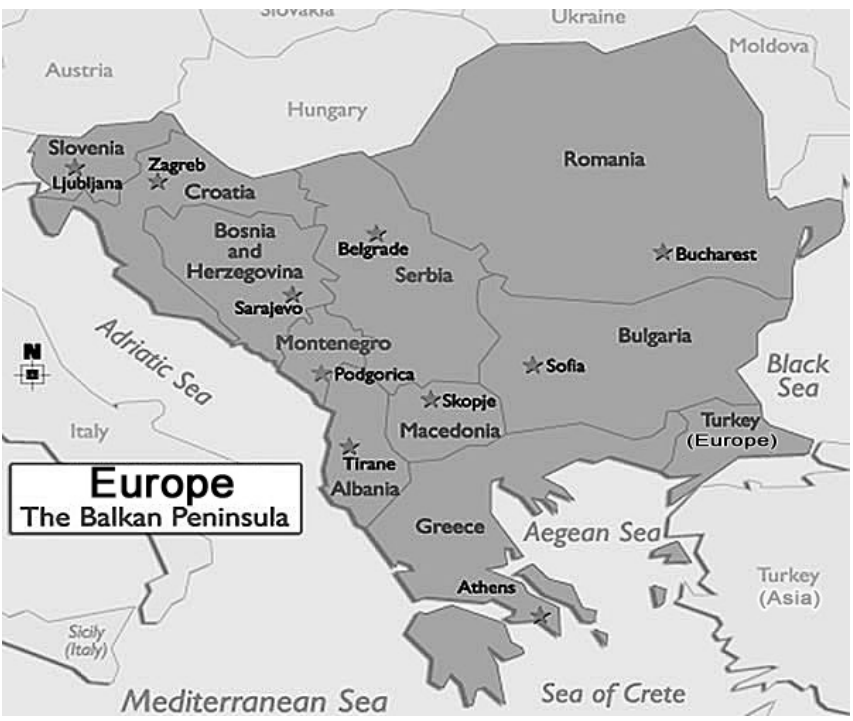

Figure 1. Balkan Peninsula. 
tute for Health and Food Safety Zenica during 2009-2017 using the Antirabies Service Protocol was performed. The research was approved by the institutional review board.

Rabies PEP cases were recorded on the basis of a consultation with a doctor (epidemiologist) and resultant administration of PEP within 3 days after an animal bite.

The questionnaire contained data on the date (month/year) of the bite/scratch, name, age, sex, place of residence (municipality), anatomical site of the bite/scratch, type (source) of animal (domestic/wildlife; stray or self/neighbor-owned), veterinary observation of the animal, and whether antirabies PEP was received.

\section{Surveillance, Prevention, and Control of Animal Rabies}

In accordance with the Veterinary Law in B\&H [14] and the State Veterinary Office decision on measures of control of infectious and parasitic diseases of animals [15], in all cases of a suspicion of animal infection or death, the animal owner must inform the nearest veterinary organization, which forwards the information to the inspector (official veterinary doctor). An authorized laboratory informs the competent inspector of the diagnostic results, and the inspector forwards the information to the authorized regional organization. In cases of a suspected or confirmed zoonosis, the veterinary inspector informs the competent health organization, as well as sending a regular monthly infectious diseases report (list $A, B$, and $C$ ) to the authorized veterinary organization. Rabies is included on list $B$ (zoonoses, or diseases caused by various animal species) [14], and are subject of mandatory notification.

\section{Prevention and Control of Human Rabies}

A process for the prevention and control of human infectious diseases, including rabies, is defined by the law $[16,17]$. The authorized antirabies service (at the cantonal level) must (urgently) report all cases of bites/contact with rabid or rabiessuspected animals to the Federal Institution of Health using a legally prescribed form (questionnaire). In cases of clinically healthy dogs and cats, the animals should followed up for a 10-day period (the 1st, 5th, and 10th days after a bite/scratch), about which the veterinary doctor should inform an epidemiologist. Only if signs of disease appear in the 10-day follow-up period are laboratory tests performed.

The questionnaire should be filled out and forwarded to the entity Institute for Public Health (FB\&H, RS, or BD, respective-
Iy). All actions relating to surveillance involve the consolidated Ministry of Civil Affairs B\&H at the state level.

The National Reference Laboratories for rabies are located at the Veterinary Faculty of Sarajevo and at the Veterinary Institute in Banja Luka. Laboratories routinely perform fluorescent antibody tests.

\section{RESULTS}

During the 2009-2017 period, a total of 1716 persons were admitted to the Rabies Service of the Epidemiology Department of the Institute for Health and Food Safety Zenica after being bitten or scratched by a rabies-suspected animal. The highest prevalence of bites/scratches was noted in 2012, with 254 (14.8\%) cases and in 2015, with 242 (14.1\%) cases, resulting in incidence rates 63.58 and 60.99/100 000 population, respectively. Bites/scratches were most frequently noted during April and May ( $n=181,10.5 \%$ and $n=163,9.5 \%$, respectively) (Table 1 ).

The patients admitted to the Rabies Service were mostly from the Zenica municipality ( $n=1278,74.5 \%$, corresponding to an incidence of $11.55 / 100000$ population). Of note, the Zenica municipality is the most urbanized municipality in ZenicaDoboj Canton as a whole, with $66.6 \%$ of the population living in urbanized areas. The second highest incidence occurred in the Doboj Jug municipality, a 100\% rural area (4.10/1000 population). In the Usora municipality, a 100\% rural area, there were no registered cases (Table 2).

Males were more frequently represented than females $(n=$ $1089,63.6 \%$ and $n=627,36.5 \%$, respectively). The average age of the bitten patients was 37.42 years (range, 1-86 years). The most commonly represented age groups were $50-64$ years and $25-49$ years ( $n=425,24.7 \%$ and $n=390,22.7 \%$, respectively). Dog bites accounted for the vast majority of cases (1634 of 1716, $95.1 \%)$, of which $1258(77.0 \%)$ were caused by stray dogs. Cats were responsible for 63 (3.6\%) bites, of which 46 (73.0\%) were stray cats. Nineteen (1.1\%) bites were caused by other animals: rats in 7 cases, mice in 3 cases, a doormouse in 1 case, a mole in 1 case, martens in 6 cases, and a rabbit in 1 case. Because it was impossible to put those animals under veterinary observation, antirabies PEP was mandatory in these cases.

Antirabies PEP was indicated in 997 (58.1\%) patients, of whom 55 (14.0\%) patients received PEP despite the fact that the bites were caused by a self-owned/neighbor-owned animal, either because it was not possible to conduct veterinary observation of the animals due to the owner's lack of coopera- 
Table 1. Seasonal distribution of patients with bites/scratches from rabies-suspected animals, 2009-2017

\begin{tabular}{|c|c|c|c|c|c|c|c|c|c|c|}
\hline Month & $\begin{array}{c}2009 \\
(400602)\end{array}$ & $\begin{array}{c}2010 \\
(400126)\end{array}$ & $\begin{array}{c}2011 \\
\text { (399 856) }\end{array}$ & $\begin{array}{c}2012 \\
(399485)\end{array}$ & $\begin{array}{c}2013 \\
(398655)\end{array}$ & $\begin{array}{c}2014 \\
(397813)\end{array}$ & $\begin{array}{c}2015 \\
(396732)\end{array}$ & $\begin{array}{c}2016 \\
(361031)\end{array}$ & $\begin{array}{c}2017 \\
(361031)\end{array}$ & Total \\
\hline January & $6(4.0)$ & $8(5.2)$ & $20(9.1)$ & $17(6.7)$ & $28(13.4)$ & $14(8.4)$ & $10(4.1)$ & $15(8.3)$ & $15(10.4)$ & $133(7.7)$ \\
\hline February & $12(8.0)$ & $5(3.3)$ & $10(4.5)$ & $25(9.8)$ & $20(9.5)$ & $13(7.8)$ & $17(7.0)$ & $11(6.1)$ & $16(11.1)$ & $129(7.5)$ \\
\hline March & $15(10.0)$ & $17(11.2)$ & $17(7.7)$ & $22(8.6)$ & $21(10.0)$ & $17(10.2)$ & $15(6.2)$ & $14(7.7)$ & $15(10.4)$ & $153(8.9)$ \\
\hline April & $18(12.0)$ & $10(6.5)$ & $20(9.1)$ & $22(8.6)$ & $21(10.0)$ & $19(11.4)$ & $30(12.4)$ & $26(14.4)$ & $15(10.4)$ & 181 (10.5) \\
\hline May & $20(13.3)$ & $15(9.9)$ & $14(6.3)$ & $25(9.8)$ & $11(5.2)$ & $18(10.8)$ & $28(11.6)$ & $14(7.7)$ & $18(12.5)$ & $163(9.5)$ \\
\hline June & $12(8.0)$ & $16(10.5)$ & $13(5.9)$ & $29(11.4)$ & $17(8.1)$ & $17(10.2)$ & $17(7.0)$ & $17(9.4)$ & $6(4.2)$ & $144(8.4)$ \\
\hline July & $17(11.3)$ & 21 (13.8) & $24(10.9)$ & $19(7.4)$ & $17(8.1)$ & $7(4.2)$ & $16(6.6)$ & $12(6.7)$ & $9(6.3)$ & 142 (8.3) \\
\hline August & $14(9.3)$ & $12(7.9)$ & $25(11.3)$ & $15(5.9)$ & $9(4.3)$ & $16(9.6)$ & $22(9.1)$ & $17(9.4)$ & $14(9.7)$ & 144 (8.4) \\
\hline September & $11(7.3)$ & $11(7.2)$ & $20(9.1)$ & $18(7.0)$ & $20(9.5)$ & $11(6.6)$ & $25(10.3)$ & $7(3.9)$ & $9(6.3)$ & $132(7.7)$ \\
\hline October & $14(9.3)$ & $4(2.6)$ & $14(6.3)$ & $19(7.4)$ & $19(9.0)$ & $12(7.2)$ & $18(7.4)$ & $16(8.9)$ & $7(4.9)$ & $123(7.1)$ \\
\hline November & $7(4.6)$ & $13(8.5)$ & $24(10.9)$ & $15(5.9)$ & $8(3.8)$ & $14(8.4)$ & $25(10.3)$ & 21 (11.7) & $12(8.3)$ & 139 (8.1) \\
\hline December & $4(2.6)$ & $20(13.2)$ & $18(8.1)$ & $28(11.0)$ & $18(8.6)$ & $8(4.8)$ & $19(7.9)$ & $10(5.6)$ & $8(5.6)$ & $133(7.7)$ \\
\hline Total (of 1716) & $150(8.7)$ & $152(8.9)$ & $219(12.8)$ & $254(14.8)$ & 209 (12.2) & $166(9.7)$ & $242(14.1)$ & $180(10.5)$ & $144(8.4)$ & $1716(100)$ \\
\hline Incidence/100 000 & 37.44 & 37.98 & 54.76 & 63.58 & 52.42 & 41.72 & 60.99 & 49.85 & 39.88 & - \\
\hline
\end{tabular}

Values are presented as number (\%).

Table 2. Distribution of patients with bites/scratches from rabies-suspected animals, 2009-2017, in the municipalities of ZenicaDoboj Canton

\begin{tabular}{lcrr}
\hline $\begin{array}{l}\text { Municipality } \\
\text { (No. of urban/rural population) } \\
\text { [\% urbanization] }\end{array}$ & $\begin{array}{c}\text { Patients presenting to the } \\
\text { Epidemiology Department }\end{array}$ & Incidence/1000 & Population \\
\hline Breza (3125/11 043) [23.0] & $37(2.1)$ & 2.61 & $14168(3.9)$ \\
\hline Doboj Jug (0/4137) [0.0] & $17(1.0)$ & 4.10 & $4137(1.1)$ \\
Kakanj (12 256/25 185) [32.7] & $109(6.3)$ & 2.91 & $37441(10.3)$ \\
Maglaj (6438/16 708) [27.8] & $29(1.7)$ & 1.25 & $23146(6.3)$ \\
\hline Olovo (2568/7589) [25.4] & $5(0.3)$ & 0.49 & $10157(2.8)$ \\
\hline Tešanj (5531/37 532) [12.8] & $66(3.8)$ & 1.53 & $43063(11.8)$ \\
\hline Usora (0/6603) [0.0] & $0(0.0)$ & 0.00 & $6603(1.8)$ \\
Vareš (3117/5775) [35.1] & $3(0.2)$ & 0.33 & $8892(2.4)$ \\
Visoko (11 552/28 386) [28.9] & $60(3.5)$ & 1.50 & $39938(11.0)$ \\
Zavidovići (9217/26 771) [25.6] & $18(1.0)$ & 0.50 & $35988(9.9)$ \\
Zenica (73 751/36 912) [66.6] & $1278(74.5)$ & 11.55 & $110663(30.4)$ \\
Žepče (5804/24 415) [19.2] & $94(5.5)$ & 3.11 & $30219(8.3)$ \\
\hline Total (126 940/237 493) [34.8] & $1716(100)$ & 4.71 & $364433(100)$ \\
\hline
\end{tabular}

Values are presented as number (\%).

tion, or because the bite was on a specific anatomic site (head, fingers) with a shorter incubation period. Roughly $15 \%$ of the patients in whom PEP was indicated did not receive PEP. Approximately $60 \%$ of the patients promptly presented at the Antirabies Service within 3 days after the animal attack.

However, antirabies PEP was not indicated for 719 (41.9\%) patients, although 380 (28.7\%) of the bites were caused by stray animals.

Only 340 (of $1716 ; 19.9 \%$ ) animals were underwent to 10 - day veterinary observation, of which 40 (11.8\%) stray and 300 (88.2\%) self/neighbor owned animals. were self-owned/neighbor-owned animals. The vast majority of stray animals ( $\mathrm{n}=$ $1282,96.9 \%$ ) did not undergo a 10-day veterinary observation. Among the 394 self-owned/neighbor-owned animals, 94 (23.9\%) did not undergo a 10-day veterinary observation (Table 3). None of animals that underwent a 10-day observation showed signs of the disease.

The largest number of injuries were at the lower part of the 
Table 3. Demographic characteristics of patients exposed to animal bites/scratches according to the animal source

\begin{tabular}{|c|c|c|c|}
\hline Variable & $\begin{array}{c}\text { Stray } \\
\text { animal }\end{array}$ & $\begin{array}{c}\text { Self-/neighbor-owned } \\
\text { animal }\end{array}$ & Total \\
\hline \multicolumn{4}{|l|}{ Sex } \\
\hline Male & 848 (64.2) & $241(61.2)$ & 1089 (63.6) \\
\hline Female & $474(35.8)$ & $153(38.8)$ & $627(36.5)$ \\
\hline Total & $1322(100)$ & $394(100)$ & $1716(100)$ \\
\hline \multicolumn{4}{|l|}{ Age (y) } \\
\hline $0-6$ & $92(7.0)$ & 72 (18.2) & $164(9.5)$ \\
\hline $7-14$ & $191(14.4)$ & $93(23.6)$ & $284(16.5)$ \\
\hline $15-24$ & $154(11.6)$ & 49 (12.4) & 203 (11.8) \\
\hline $25-49$ & $319(24.1)$ & $71(18.0)$ & $390(22.7)$ \\
\hline $50-64$ & $356(26.9)$ & $69(17.5)$ & $425(24.7)$ \\
\hline$>65$ & $210(16.0)$ & $40(10.1)$ & $250(14.5)$ \\
\hline Total & $1322(100)$ & $394(100)$ & $1716(100)$ \\
\hline \multicolumn{4}{|l|}{ Bite site } \\
\hline Head, face, and neck & $23(1.7)$ & $22(5.6)$ & $45(2.6)$ \\
\hline Upper extremities & $331(25.0)$ & $143(36.3)$ & $474(27.6)$ \\
\hline Lower extremities & $876(66.3)$ & $168(42.6)$ & $1044(60.8)$ \\
\hline Trunk & $14(1.1)$ & $15(3.8)$ & $29(1.7)$ \\
\hline Multiple & $78(5.9)$ & $46(11.7)$ & $124(7.2)$ \\
\hline Total & $1322(100)$ & $394(100)$ & $1716(100)$ \\
\hline \multicolumn{4}{|l|}{ Type of animal } \\
\hline Dog & $1258(95.1)$ & $376(95.4)$ & $1634(95.1)$ \\
\hline Cat & $46(3.4)$ & $17(4.3)$ & $63(3.6)$ \\
\hline Other ${ }^{1}$ & $18(1.3)$ & $1(0.2)$ & $19(1.1)$ \\
\hline Total & $1322(100)$ & $394(100)$ & $1716(100)$ \\
\hline \multicolumn{4}{|c|}{ Antirabies postexposure prophylaxis indicated } \\
\hline Yes & $942(71.3)$ & $55(14.0)$ & $997(58.1)$ \\
\hline No & $380(28.7)$ & $339(86.0)$ & $719(41.9)$ \\
\hline Total & $1322(100)$ & $394(100)$ & $1716(100)$ \\
\hline \multicolumn{4}{|c|}{ Animals that underwent veterinary observations } \\
\hline Yes & $40(3.1)$ & $300(76.1)$ & $340(19.9)$ \\
\hline No & $1282(96.9)$ & $94(23.9)$ & $1376(80.1)$ \\
\hline Total & $1322(100)$ & $394(100)$ & $1716(100)$ \\
\hline
\end{tabular}

Values are presented as number (\%).

${ }^{1}$ Rat (7), mouse (3), doormouse (1), mole (1), marten (6), rabbit (1).

lower extremity, in 715 (41.7\%) cases, followed by the hand (upper extremity) in 221 (12.9\%) cases. The forearm and fingers were affected in $127(7.4 \%)$ and $76(4.4 \%)$ cases, respectively, and the face, head, and neck in 45 (2.6\%) cases. In 124 (7.2\%) patients, injuries were present at multiple sites of the body (Table 4).
Table 4. Anatomical distribution of animal bites/scratches

\begin{tabular}{|c|c|}
\hline Anatomical location & n (\%) \\
\hline \multicolumn{2}{|l|}{ Head, face, and neck } \\
\hline Head & $6(0.3)$ \\
\hline Face (forefront) & $16(0.9)$ \\
\hline Cheek & $5(0.3)$ \\
\hline Lip & $7(0.4)$ \\
\hline Ear & $3(0.2)$ \\
\hline Neck & $8(0.5)$ \\
\hline Total & $45(2.6)$ \\
\hline \multicolumn{2}{|l|}{ Upper extremities } \\
\hline Hand & $221(12.9)$ \\
\hline Forearm & $127(7.4)$ \\
\hline Finger & $76(4.4)$ \\
\hline Upper arm & $29(1.7)$ \\
\hline Elbow & $10(0.6)$ \\
\hline Palm & $5(0.3)$ \\
\hline Metacarpus & $2(0.1)$ \\
\hline Thumb & $3(0.2)$ \\
\hline Total & $474(27.6)$ \\
\hline \multicolumn{2}{|l|}{ Lower extremities } \\
\hline Lower leg & $715(41.7)$ \\
\hline Upper leg (thigh) & $242(14.1)$ \\
\hline Butt & $41(2.4)$ \\
\hline Knee & $23(1.3)$ \\
\hline Foot & $12(0.7)$ \\
\hline Heel & $5(0.3)$ \\
\hline Toe & $1(0.0)$ \\
\hline Ankle joint & $5(0.3)$ \\
\hline Total & $1044(60.8)$ \\
\hline \multicolumn{2}{|l|}{ Trunk } \\
\hline Thorax & $13(0.7)$ \\
\hline Back & $7(0.4)$ \\
\hline Abdomen & $2(0.1)$ \\
\hline Shoulder & $7(0.4)$ \\
\hline Total & $29(1.7)$ \\
\hline Multiple sites & $124(7.2)$ \\
\hline Total overall & $1716(100)$ \\
\hline
\end{tabular}

\section{DISCUSSION}

In the period of 2009-2017, there were no human rabies cases in the Zenica-Doboj Canton. In contrast, in a province in China, 21 human rabies cases were diagnosed from 2007 to 2014 [18]. During a period of 19.5 years, a total of 1839 rabies cases were registered in the Philippines, all patients died and most had an obvious history of an animal bite or scratch [2]. 
The last indigenous human rabies case in the territory of the former Yugoslavia (before 1991) was in 1974 [19].

The incidences of animal bites/scratches in this study is far lower than has been reported in some other regions of the world. In Lorestan Province (western Iran), an incidence of 223.23/100 000 population was recorded in 2004-2014 [1], and in Vietnam an even higher rate was noted of 429.55/100 000 in 2005-2015 [3].

Among our population, bites were most frequently recorded during the spring months (April and May), and the lowest incidence was observed in October. In contrast, human rabies cases have been more frequently reported in the summer and autumn [18] suggesting that farming activities during these months may be a risk factor for animal attacks [20]. Other studies attributed rabies seasonality to animal behavior (seeking food in the winter or early spring period) [21,22].

In our study, females were bitten half as often as males, which is a common finding on the world level $[2,18,23]$. All age groups were almost equally involved in our study, although the 50-64 age and $\geq 65$ age groups were more frequently represented, similar to the findings of the report from China [18]. Children (less than 15 years of age) accounted for $26 \%$ of cases in our study, which is much lower than the world average of $40 \%$ [23]. Usually, adults are more commonly bitten than children according to most reports $[2,18]$. The average age of the bitten patients was 37.42 years in our study, suggesting that a younger population was involved in comparison with the average of 50 years in the report from China [18]. However, people of all ages can be bitten $[2,18]$.

A significant number of patients were from the canton city capital; moreover, there were no cases reported from one $100 \%$ rural municipality. In the study from the Philippines, almost one-quarter of human cases derived from the city of Manila [2]. In a previous report, it was found that the majority of patients came from lower socioeconomic groups, with insufficient knowledge and/or resources, resulting in inappropriate medical care [2].

The largest number of injuries occurred on the lower and upper extremities, mostly on the lower part of the leg (41.7\%) and on the hands (12.9\%), respectively, which is logical because the legs are easy to access when attacking and because the hands can be used defensively. In $7.2 \%$ of patients injuries were present at multiple sites of the body, and they were associated with contusions and bone fractures because of the person's inability to resist the animal attack successfully. Our findings are in concordance with other reports [2]. The prevalence of upper extremity and face/head/neck bites was nonnegligible (27.6\% and $2.6 \%$, respectively); such bites are of concern, because they have a shorter incubation period before disease appearance than is the case for bites on the lower extremities [2].

Dog bites/scratches were most common, followed (with a much lower frequency) by cat bites, in which stray animals were mostly involved. Generally, domestic animals are vectors in $70 \%$ of cases, mostly dogs $[2,18]$. In the FB\&H and BD, the population of dogs with a known owner is unknown, while in the RS, it is estimated to be 50000 . The stray dog population has posed a problem in both uburban and urban areas of Zenica-Doboj Canton since the end of the recent war (i.e., from 1996 onward). Two registered shelters exist in Zenica-Doboj Canton (in Zenica and Tešanj), but they are not capable to cover the entire stray dog population. Similarly, the population of foxes in the canton is not known.

In this study, PEP was indicated in $58.1 \%$ of patients. Although all patients were informed about the possible consequences after an animal bite, approximately $15 \%$ discontinued PEP treatment on their own initiative.

Antirabies PEP cases are recorded on the basis of a consultation with a doctor and the resultant administration of PEP, mostly within 3 days (or more) after a bite by an animal (mainly dogs) without accompanying laboratory confirmation [3]. Dimaano et al. [2] reported that in the Philippines, $92 \%$ of patients did not seek a proper medical consultation, and only $22.5 \%$ of patients received PEP, largely for cost reasons; Wallace et al. [24] reported that $20.8 \%$ of patients received PEP in Haiti, and Ren et al. [18] reported that only $1.1 \%$ of patients finished the full PEP regimen in China. An important public health task is to promote the safety and effectiveness of PEP in preventing rabies, with all its consequences, among all exposed persons [25].

From 1990 onwards, rabies was eradicated from terrestrial mammals (principally the red fox) in most Central and Western European countries through wild animal vaccination programs [26], resulting in rabies-free countries [27]. Despite vaccination programs, rabies is still endemic in many countries, largely as a result of financial limitations and poor infrastructure [27].

In the second half of 2010, a vaccination program in wildlife focusing on rabies that covered the whole territory of $\mathrm{B} \& \mathrm{H}$ was introduced. None of the tested foxes during vaccination monitoring program were positive; $70-80 \%$ of the tested foxes re- 
ceived the vaccine several times, and $50-75 \%$ of the foxes were immunized [26].

The continued vaccination of wildlife against rabies in $\mathrm{B} \& \mathrm{H}$, as well as in other Balkan countries (Figure 1), especially in those neighboring B\&H (Croatia, Serbia, and Montenegro) is an important consideration. Eleven oral vaccination campaigns have been completed, leading to reduced disease incidence and wildlife reservoirs. The number of rabies cases in B\&H in foxes declined from 83 in 2008 to 0 during 2015-2016. The last case was observed in a fox in October 2013 in Laktaši, and the latest case of rabies in domestic animals was observed in a dog in September 2014 (Gradačac).

The vaccination, marking, and registry of dogs are the responsibility of authorized veterinary organizations/services on the municipality (community) level. Vaccination presently only depends on the initiative of the animal owner. A significant number of owners do not follow this mandatory legal obligation.

Control of the stray dog population is the responsibility of local communities. No unique registry of dog owners or records of the number of stray dogs exist. According to the study of Katica et al. [28] in the period 2008-2009, the number of stray dogs in the Zenica-Doboj Canton was almost half of the entire stray dog population of the 6 cantons of B\&H (24.4\% of the B\&H territory), comprising a total of 10000 (out of 22050 ). Until 2009, when the law on animal welfare was passed, the problem of stray dogs was mainly solved by euthanizing the animals; again, Zenica-Doboj Canton had the highest number of euthanized dogs.

We have no exact data about the vaccination coverage of dogs in Zenica-Doboj Canton. All veterinary services are privatized, which additionally complicates the situation; the exact number of the dog population and the number of vaccinated or neutered dogs are not known. For now, only members of non-governmental organizations are working to implement the law against animal euthanasia.

The previous study conducted in China showed that the coverage of dog immunization in rural areas was only 1.2-2.8\% [18], although better results (45\%) were reported in the study from Haiti [24]. According to the WHO, 70\% is a good coverage rate, but this rate can be difficult to achieve in developing countries [29]. In a study conducted in Malawi, although 97\% of the dog population was owned, only $53 \%$, out of the $79 \%$ examined dogs had been vaccinated at a station point, and $26 \%$ had been vaccinated by door-to-door vaccination [30].
Mazeri et al. [31] found that distance from the household and socioeconomic status played an important role in promoting attendance to vaccination services. Similar results were shown by Castillo-Neyra et al. [32].

Our study had several limitations. We lacked data on how many people were actually bitten by dogs and cats, since the recorded cases were only based on doctor consultations during which PEP was administered. It is likely that bites were underestimated, especially in rural/mountain communities.

In order to detect zoonotic pathogens as early as possible, zoonoses should be defined as a high priority. The USA Centers for Disease Control and Prevention developed the One Health Zoonotic Disease Prioritization tool as a multisectoral approach to rank a country's zoonotic diseases, and most of the involved countries recorded the following zoonoses: influenza virus, rabies, brucellosis, and anthrax [33].

In conclusion, this study underscores the importance of reductions of the stray dog population, registration and preventive vaccination of dogs, enforcement of veterinary sanitary measures, cooperation with hunting organizations, and promotion and education for successful rabies control. The One Health framework, recently established at our institute, is an important step in the better prevention and control of zoonoses, including rabies and brucellosis, in Zenica-Doboj Canton.

\section{CONFLICT OF INTEREST}

The authors have no conflicts of interest associated with the material presented in this paper.

\section{ORCID}

Selma Uzunović https://orcid.org/0000-0003-1825-1572

Muhamed Skomorac https://orcid.org/0000-0002-18616044

Fatima Bašić https://orcid.org/0000-0001-8306-6010

Ivona Mijač-Musić https://orcid.org/0000-0003-2103-806X

\section{REFERENCES}

1. Sharafi AC, Tarrahi MJ, Saki M, Sharafi MM, Nasiri E, Mokhayeri H. Epidemiological study of animal bites and rabies in Lorestan Province in west of Iran during 2004-2014 for preventive purposes. Int J Prev Med 2016;7:104.

2. Dimaano EM, Scholand SJ, Alera MT, Belandres DB. Clinical and 
epidemiological features of human rabies cases in the Philippines: a review from 1987 to 2006. Int J Infect Dis 2011;15(7): e495-e499.

3. Lee HS, Thiem VD, Anh DD, Duong TN, Lee M, Grace D, et al. Geographical and temporal patterns of rabies post exposure prophylaxis (PEP) incidence in humans in the Mekong River Delta and Southeast Central Coast regions in Vietnam from 2005 to 2015. PLoS One 2018;13(4):e0194943.

4. World Health Organization. Human rabies: 2016 updates and call for data. Wkly Epidemiol Rec 2017;92(7):77-86.

5. WHO Collaborating Centre for Rabies Surveillance and Research. Information surveillance report. Rabies Bull Eur 2013; 37(2):3-24.

6. World Health Organization. Rabies vaccines. WHO position paper. Wkly Epidemiol Rec 2007;82(49-50):425-435.

7. WHO Collaborating Centre for Rabies Surveillance and Research. Information surveillance report. Rabies Bull Eur 1977; 1(1):1-2.

8. Kodrnja E. Ten years of counteract against the rabies. Vet Arh 1959;29(5-6):132-144 (Serbian).

9. Rukavina LJ, Vaupotic A, Forsek Z, Saptalenko J. Occurence of rabies in animals of the northeastern Bosnia with reference ot the factors suitable for the maintenance and spread of the infection. Vet Glas 1973;27(10):743-750 (Serbian).

10. WHO Collaborating Centre for Rabies Surveillance and Research. Information surveillance report. Rabies Bull Eur 1977; 1(2):10-11.

11. Djuricic B, Petrovic M, Panjevic Dj, Valcic M. Epizootic situation of rabies in Yougoslavia in the period 1977-1987. Veterinarski Glasnik 1988;42(8):483-493 (Serbian).

12. WHO Collaborating Centre for Rabies Surveillance and Research. Information surveillance report. Rabies Bull Eur 2001; 25(3):3-32.

13. Velić R, Bajrović T, Zvizdić S, Velić L, Hamzić S. Genetic characterisation of rabies virus isolates in Bosnia and Herzegovina. Bosn J Basic Med Sci 2008;8(3):239-244.

14. Government of Bosnia and Herzegovina. The Veterinary Law in Bosnia and Herzegovina; 2002 [cited 2018 Mar 20]. Available from: http://www.vet.gov.ba/pdffiles/Zakon_O_Vetrinarstvu/Veterinary\%20Law.pdf.

15. Government of Bosnia and Herzegovina. Decision on infectious diseases; 2003 [cited 2018 Mar 20]. Available from: http://extwprlegs1.fao.org/docs/pdf/bih148466.pdf (Bosnian).

16. Government of Bosnia and Herzegovina. Legislative of pro- tection of population from infectious diseases; 2005 [cited 2018 Mar 20]. Available from: http://www.fmoh.gov.ba/index. php/zakoni-i-strategije/zakoni/zakon-o-zastiti-stanovnistvaod-zaraznih-bolesti (Bosnian).

17. Government of Bosnia and Herzegovina. Rulebook of infectious diseases reporting; 2012 [cited 2018 Mar 20]. Available from: http://www.zzjzfbih.ba/wp-content/uploads/2017/09/ Pravilnik-o-prijavljivanju-Zaraznih-bolesti-101-2012-ilovepdf-compressed.pdf (Bosnian).

18. Ren J, Gong Z, Chen E, Lin J, Lv H, Wang W, et al. Human rabies in Zhejiang Province, China. Int J Infect Dis 2015;38:77-82.

19. Pasteur Institute. Rabies report of 1953-1991. Novi Sad: Pasteur Institute; 1992 (Serbian).

20. Yin CP, Zhou H, Wu H, Tao XY, Rayner S, Wang SM, et al. Analysis on factors related to rabies epidemic in China from 20072011. Virol Sin 2012;27(2):132-143.

21. Tenzin, Dhand NK, Ward MP. Patterns of rabies occurrence in Bhutan between 1996 and 2009. Zoonoses Public Health 2011;58(7):463-471.

22. Messenger SL, Smith JS, Rupprecht CE. Emerging epidemiology of bat-associated cryptic cases of rabies in humans in the United States. Clin Infect Dis 2002;35(6):738-747.

23. Kassiri H, Kassiri A, Mosavi R, Jashireh A, Lotfi M. Prevalence rate and epidemiological determinants of animal bite in Ahvaz County, Khuzestan Province, Southwestern Iran. J Acute Dis 2014;3(1):51-55.

24. Wallace R, Etheart M, Ludder F, Augustin P, Fenelon N, Franka R, et al. The health impact of rabies in Haiti and recent developments on the path toward elimination, 2010-2015. Am J Trop Med Hyg 2017;97(4_Suppl):76-83.

25. Nguyen HT, Tran CH, Dang AD, Tran HG, Vu TD, Pham TN, et al. Rabies vaccine hesitancy and deaths among pregnant and breastfeeding women - Vietnam, 2015-2016. MMWR Morb Mortal Wkly Rep 2018;67(8):250-252.

26. European Commission. Improvement of animal health control through the vaccination against rabies. IPA National Programme 2010 - Bosnia and Herzegovina. Fiche 14 "Animal Health" [cited 2018 May 30]. Available from: https://ec.europa.eu/neighbourhood-enlargement/sites/near/files/pdf/bosnia_and_ herzegovina/ipa/2010/part-1/pf_14_ipa_2010_rabies_en. pdf.

27. Mutinelli F, Stankov S, Hristovski M, Seimenis A, Theoharakou $\mathrm{H}$, Vodopija I. Rabies in Italy, Yugoslavia, Croatia, Bosnia, Slovenia, Macedonia, Albania \& Greece. In: King AA, editor. Historical perspective of rabies in Europe and the Mediterranean 
Basin: a testament to rabies by Dr Arthur A. King. Geneva: World Health Organization; 2004, p. 98-108.

28. Katica M, Gradascevic N, Hadzimusic N, Obradovic Z, Mujkanovic $R$, Mestric $E$, et al. Widespread of stray dogs: methods for solving the problem in certain regions of Bosnia and Herzegovina. Int J Res Granthaalayah 2017;5(6):414-422.

29. Millien MF, Pierre-Louis JB, Wallace R, Caldas E, Rwangabgoba $J M$, Poncelet $J L$, et al. Control of dog mediated human rabies in Haiti: no time to spare. PLoS Negl Trop Dis 2015;9(6):e0003806.

30. Gibson AD, Handel IG, Shervell K, Roux T, Mayer D, Muyila S, et al. The vaccination of 35,000 dogs in 20 working days using combined static point and door-to-door methods in Blantyre,
Malawi. PLoS Negl Trop Dis 2016;10(7):e0004824.

31. Mazeri S, Gibson AD, Meunier N, Bronsvoort BM, Handel IG, Mellanby RJ, et al. Barriers of attendance to dog rabies static point vaccination clinics in Blantyre, Malawi. PLoS Negl Trop Dis 2018;12(1):e0006159.

32. Castillo-Neyra R, Brown J, Borrini K, Arevalo C, Levy MZ, Buttenheim $A$, et al. Barriers to dog rabies vaccination during an urban rabies outbreak: qualitative findings from Arequipa, Peru. PLoS Negl Trop Dis 2017;11(3):e0005460.

33. Salyer SJ, Silver R, Simone K, Barton Behravesh C. Prioritizing zoonoses for global health capacity building-themes from one health zoonotic disease workshops in 7 countries, 20142016. Emerg Infect Dis 2017;23(Suppl 1):S55-S64. 